\title{
First in situ analyses of nitrogen in primitive subduction-related melts
}

\author{
EVELYN FÜRI ${ }^{1}$, MAXIM V. PORTNYAGIN ${ }^{2}$, NIKITA \\ MIRONOV $^{3}$, CÉCILE DELIGNY $^{4}$, ANDREY GURENKO ${ }^{4}$, \\ ROMAN BOTCHARNIKOV ${ }^{5}$ AND FRANCOIS HOLTZ ${ }^{6}$ \\ ${ }^{1}$ Université de Lorraine/CNRS \\ ${ }^{2}$ GEOMAR Helmholtz Centre for Ocean Research Kiel \\ ${ }^{3}$ V.I. Vernadsky Institute of Geochemistry and Analytical \\ Chemistry \\ ${ }^{4}$ Université de Lorraine \\ ${ }^{5}$ Johannes Gutenberg Universität Mainz \\ ${ }^{6}$ Leibniz Universität Hannover \\ Presenting Author: efueri@crpg.cnrs-nancy.fr
}

A quantitative understanding of nitrogen fluxes and preeruptive magmatic concentrations in subduction zones is key for constraining the $\mathrm{N}$ recycling efficiency between Earth's internal and external reservoirs. Although the three-component mixing model of Sano et al. [1], for example, provides a means to estimate the relative contributions from air, subducted sediments, and the mantle to the total $\mathrm{N}$ content of gas and/or water samples from arc volcanoes and associated hydrothermal systems, assessing the $\mathrm{N}$ content of primitive arc magmas and their mantle source remains a challenge. Given that melt inclusions (MIs) in Mg-rich olivine represent the best proxies for primary arc melts, we applied, for the first time, an in situ high-resolution secondary ion mass spectrometry (SIMS) method [2] to determine the $\mathrm{N}$ concentration in olivine-hosted MIs from Klyuchevskoy volcano in Kamchatka. To reverse the effects of post-entrapment modification processes, the MIs were partially to completely homogenized at high temperatures $\left(1150-1400^{\circ} \mathrm{C}\right)$ and pressures ranging from 0.1 to $500 \mathrm{MPa}$ under dry to $\mathrm{H}_{2} \mathrm{O}$-saturated conditions at variable oxygen fugacities (CCO to QFM+3.3) [3]. After the experiments, $\mathrm{N}$ concentrations in water-rich $\mathrm{MI}$ glasses correlate positively with $\mathrm{H}_{2} \mathrm{O}$ and $\mathrm{CO}_{2}$ contents as well as with $\mathrm{N} / \mathrm{CO}_{2}$ ratios, and negatively with the volume of the remaining fluid bubble. Glasses of completely homogenized (fluid bubblefree) MIs contain up to $25.7 \pm 0.5 \mathrm{ppm} \mathrm{N}$, whereas glasses of three unheated (natural, glassy) MIs have significantly lower $\mathrm{N}$ concentrations of $\sim 1 \pm 0.3 \mathrm{ppm}$. The $\mathrm{N}-\mathrm{CO}_{2}$ characteristics of completely homogenized MIs indicate that melts feeding Klyuchevskoy volcano are strongly enriched in both $\mathrm{N}$ and $\mathrm{CO}_{2}$ compared to primary mid-ocean ridge melts, thus indicating subduction of large amounts of $\mathrm{N}$ and its (partial) return to the crust and atmosphere by arc-related magmatism.

[1] Sano et al. (1998), GRL 25, 2289-2292. [2] Füri et al. (2018), Chem Geol 493, 327-337. [3] Mironov et al. (2015), EPSL 425, 1-11. 